\title{
Implementation of Learning Organization in School
}

\author{
Nor Hafiza Ahmad*, Norliah Kudus, Sharifah Sakinah Syed Ahmad \\ Institute of Technology and Entrepreneurship Management, Universiti Teknikal Malaysia Melaka, 76100, Malaysia. \\ *Corresponding author: M08191004@student.utem.edu.my
}

Article history: Received: 06 March 2021 Received in revised form: 06 May 2021 Accepted: 09 June 2021 Published online: 31 August 2021

\begin{abstract}
The human resource development aspect is an important and significant element in ensuring a school organization to achieve and realize the vision and goals of the school organization. To ensure that school organizations respond appropriately, responsively and efficiently to all challenges and expectations in the 21st century, school organizations are required to implement transformation and transition into a genuine learning organization in order to survive and maintain their excellence. The current study aims to investigate the level of implementation of learning organization practices in school organization according to teachers' perceptions in Melaka Tengah District, Melaka. This study employed a quantitative research design. Using the instrument, Learning Organisation Practices Profile (LOPP), the study collected data from 500 teachers from thirteen school organization located in Melaka Tengah District, Melaka that is chosen based on cluster and simple random sampling. Statistical Package for Social Science (SPSS) 25 for Windows was used to analyze the Learning Organization practices in the school organization. Based on the analysis of mean scores obtained from the twelve components contained in LOPP, it was found that the level of learning organization practice in the school organizations studied is at a high level. The most practiced components in the school organization studied are organizational climate, information flow and executive practices while the least practiced and need to be given more emphasis are the reward and recognition component, management practices and performance goals and feedback. The findings of this study show the importance of developing human resources by cultivating a culture of learning organization in school organizations.
\end{abstract}

Keywords: Learning Organization, Human Resources Development, Education Transformation, Secondary School Organization

\begin{abstract}
Abstrak
Aspek pembangunan sumber manusia adalah elemen penting dalam memastikan organisasi sekolah mencapai dan merealisasikan visi dan matlamatnya. Untuk memastikan bahawa organisasi sekolah bertindak balas dengan tepat, responsif dan cekap terhadap semua cabaran dan harapan pada abad ke-21, organisasi sekolah dituntut untuk melaksanakan transformasi dan peralihan menjadi organisasi pembelajaran yang tulen agar dapat bertahan dan mengekalkan kecemerlangan mereka. Kajian ini dilaksanakan bertujuan untuk mengkaji tahap pelaksanaan amalan organisasi pembelajaran dalam organisasi sekolah mengikut persepsi guru di Daerah Melaka Tengah, Melaka. Kajian ini menggunakan reka bentuk penyelidikan kuantitatif. Dengan menggunakan instrumen tersebut, Learning Organics Practices Profile (LOPP), kajian ini mengumpulkan data dari 500 guru dari tiga belas organisasi sekolah yang terletak di Daerah Melaka Tengah, Melaka yang dipilih secara persampelan rawak kluster dan rawak mudah. Statistical Package for Social Science (SPSS) 25 untuk Windows digunakan untuk menganalisis amalan Organisasi Pembelajaran di organisasi sekolah. Berdasarkan analisis skor min yang diperoleh dari dua belas komponen yang terdapat dalam LOPP, didapati bahawa tahap amalan organisasi pembelajaran di organisasi sekolah yang dikaji berada pada tahap tinggi. Komponen yang paling diamalkan dalam organisasi sekolah yang dikaji adalah iklim organisasi, aliran maklumat dan amalan eksekutif sementara yang paling tidak diamalkan dan perlu diberi penekanan lebih banyak adalah komponen penghargaan dan pengiktirafan, amalan pengurusan dan matlamat prestasi dan maklum balas. Dapatan kajian ini menunjukkan pentingnya mengembangkan sumber manusia dengan memupuk budaya organisasi pembelajaran di organisasi sekolah.
\end{abstract}

Kata kunci: Organisasi Pembelajaran, Pembangunan Sumber Manusia, Perubahan dan Transformasi Pendidikan, Organisasi Sekolah Menengah

(C) 2021 Penerbit UTM Press. All rights reserved

\subsection{INTRODUCTION}

The education system in Malaysia has undergone various changes and transformations in line with the rapid changes taking place globally due to the process of globalization and advances in the fields of information, communication, and technology. These dynamic and nonstatic changes also require changes to be implemented by school organizations that play a key role in realizing all the goals and visions formulated by the Ministry of Education Malaysia (MOE). To elevate the education system in Malaysia on par with the education system owned by developed countries, MOE has formulated the Malaysian Education Blueprint (MEB) which took place from 2013 to 2025. Introduction of MEB is an idea of MOE to ensure the sustainability of the education system in Malaysia and able to generate human capital that can drive the country's progress in the future.

The role of the school organization in being the main pillar that serves to fulfill every goal and direction that has been pursued by the MOE can no longer be denied. School organizations need to change existing practices to find a balance with changes that occur in the landscape of the educational environment or more precisely said to be more flexible and adaptive to the process of change and 
transformation (Chin, 2014). If school organizations fail to implement transitions or changes in line with global change, school organizations will face the risk of becoming irrelevant and losing influence (Savas et al., 2013). School organizations need to take seriously the challenges of change and transformation that occur in the environmental landscape and then plan and formulate effective strategies to manage those challenges in ensuring the survival and growth of the school organization (Abenga, 2018).

The effectiveness of a school organization in carrying out the task entrusted to strengthen the Malaysian education system is highly dependent on the main human resources that serve in the school organization, namely teachers. This is because according to behavioral science, the progress of a school organization is highly dependent on the efficient use of human resources in the organization (Ghadermarzi et al., 2020). Teachers are the mainstay that plays a very significant role in ensuring the effectiveness of the student learning process (Dahl, 2019). Teachers also serve as developers, strengtheners, and builders of students' skills towards producing quality human capital to cope with the rapid process of globalization. (A. M. N. Firdaus et al., 2016).

In line with the changes and transformations that are taking place in the current educational environment landscape, teachers as the main human resource in schools are not only required to be presenters of learning content but also urged to be 'highly knowledgeable workers' (Schleicher, 2012). Teachers are also required to constantly improve the professional knowledge they possess further improving their profession (Prenger et al., 2019). Teachers nowadays not only need to focus on specific content based on their respective fields but also need to identify the best methods and tools to ensure the effectiveness of the teaching and learning process conducted daily.

However, the findings of previous studies clearly show that the level of teacher commitment is still at a moderate level (Mei et al., 2017). In fact, statistics from the Ministry of Education Malaysia itself show that teachers in Malaysia only manage to deliver 50\% of their teaching effectively (Kementerian Pendidikan Malaysia, 2013). Low commitment among teachers will contribute to a lack of credible, dedicated and highly competent teachers who will always have the sincerity and diligence to try and explore new alternatives and possibilities that are capable of producing a more memorable teaching and learning system. Therefore, an effective initiative must be taken immediately to ensure that teachers always strive to improve their professional knowledge and subsequently improve their professionalism (Prenger et al., 2019).

Considering the importance of the role of teachers in ensuring the sustainability of the national education system, most organizations, researchers, and practitioners in the field of education are now committed and strive to determine factors that can help to produce quality teachers (Donehower Paul et al., 2020). To produce human resources that are high-quality teachers who are dedicated, credible, open to the process of change and transformation, dare to try and explore various alternatives and new possibilities of the organization, schools now need to implement a new paradigm shift and immediately transform into a learning organization pure. School organizations are encouraged to implement the learning process continuously to meet the challenges of future changes due to dynamic and non-static technological changes (Odor, 2018). School organizations need to be able to generate and disseminate new knowledge among human resources at all levels of the organization to enable school organizations to cope with this complex change.

Learning organization is a practice that enables school organizations to have a structure and culture that is open to change and encourages the process of innovation that can be implemented through the learning process (Santa, 2015). When school organizations implement the practice of learning organization as a core in service, school organizations will be able to implement reforms and generate positive energy to the organization to be adaptable and adaptive to a challenging environment and change consistently (Vijayabanu et al., 2015). The implementation of the practice of this learning organization also enables school organizations to be more competent and continue to survive despite being pressured by various changes and transformations in the educational landscape (Ghadermarzi et al., 2020).

Various benefits will be obtained when the school organization successfully implements the practice of learning organization. There is a strong consensus among scholars that school organizations will be more competent and able to be superior competitors in the field if school organizations can make themselves good at learning and then transform into a learning organization (Mohd-zainal et al., 2017). The school organization will also be able to be a superior competitor and difficult to match when transformed into a learning organization (Odor, 2018). Although various benefits have been discussed by previous researchers that school organizations will gain when successfully implementing learning organization practices, but the number of empirical studies that examine the level of implementation of learning organization practices in school organizations is still less and needs more research in this area. (Retna \& Tee, 2006). In fact, the findings of previous studies also state that there are still schools in Malaysia that fail to implement the practice of learning organization successfully even though this practice has been proven to be able to smooth the process of school administration and management. (Sabariah Sharif et al., 2013). Although the concept of learning organization practice has been introduced over the past 3 decades, but this concept is still considered new in school organization and requires more research leading to the implementation of learning organization practice in school organization. (Alzahrani et al., 2016). Most of the studies that examine the implementation of learning organization practices in school organizations are also more voiced among developed countries than developing countries such as Malaysia. (Abenga, 2018). The implementation of the practice of learning organizations in school organizations is still at a vague stage because of the lack of empirical studies to prove the continuity of the practice of learning organizations in producing excellent school achievements. (Stoll \& Kools, 2017). Therefore, researchers feel the need to conduct a study to study the perception of human resources on the level of implementation of learning organization practices in secondary schools in the district of Melaka Tengah, Melaka. This study will be an important indicator for KPM, JPN, and PPD to improve the practice of learning organization in school organizations to produce school organizations that have excellent and distinguished performance.

\subsection{LITERATURE REVIEW}

\subsection{Continuous Learning in School Organization}

The school organization is a man-made organization that needs to constantly interact with the environment that is undergoing rapid transformation and change in line with current developments. This is in line with the perspective that has been put forward by open system theory which sees the school organization as an open organization that receives a greater and significant impact due to the process of 
change and transformation that takes place in the environmental landscape (Wahidin, 2013). The changes taking place in the national education landscape are driven by the process of globalization and advances in technology, communication, and information that have a great influence on the management aspects of school organizations. The transformations and changes that have taken place in the national education landscape have had a tremendous impact on school organizations (Van Wart et al., 2017). To enable school organizations to face and manage these transformations and changes effectively, effectively, and efficiently, school organizations are required to always be prepared with effective strategic planning to maintain the continuity and sustainability of school organizations (Pedler \& Burgoyne, 2017).

To enable school organizations to cope with the process of change and be able to manage the changes that occur effectively, a large number of researchers and organizational management experts suggest that organizations are committed to implementing the transition towards becoming a genuine learning organization (Kudus et al., 2011). The idea of encouraging schools to implement change into a genuine learning organization has been a hotly debated issue as this practice is seen as a valuable internal process that can provide added value to the organization in turn contributing to the success of the school organization (Harris \& Jones, 2018). It is common knowledge that the most important and most valuable asset owned by a school organization is the human resources it serves. Thus, to enable the school organization to continue to survive, and to grow despite various external and internal challenges, it is essential for human resources at every level in the school organization to implement a learning process that will enable the school organization to realize all the goals it has dreamed of (Marquardt, 2002).

Through the continuous implementation of the learning process at the individual, team, and organizational levels, an increase in organizational knowledge will occur and enable the organization to become more flexible and adaptive and successfully adapt to changing environments (R. Firdaus, 2016). The increase and proliferation that occurs in school organizations will increase the confidence of all stakeholders and ensure that school organizations can remain relevant. This is because the practice of learning organization places a high emphasis on learning that has been implemented by human resources both in terms of knowledge and new skills that can guarantee the successful implementation of learning organization practices in school organizations (Garvin et al., 2008).

\subsection{Importance of Human Resources in the School Organization}

Due to the transformation and change triggered by various factors such as globalization, technological advancement, information and communication, and the industrial revolution 4.0, then school organizations are also required to immediately implement changes in every aspect to ensure school organization remains relevant and sustainable. Transition or process of change in the organization refers to the transition implemented by the organization from the existing practices to much better practices and able to guarantee a more encouraging organizational performance (Lunenburg, 2011). Organizational change management is a systematic process where school organizations need to build concepts, implement and then evaluate the change efforts that have been executed to achieve the desired results (Hassan, Ahmad, and Boon, 2018). To ensure that the performance of school organizations continues to improve and become a superior competitor in the field, school organizations need to adopt effective and efficient change management (Mellor, 2018).

The role of human resources in achieving all the visions and objectives that have been formulated by the school organization can no longer be taken lightly, especially in a complex and constantly changing environmental landscape (Thi \& Hai, 2019). The findings of studies conducted by previous researchers in this field clearly show that the failure of organizational change initiatives in an organization is due to the attitude of human resources towards those changes that are usually shrouded in fear and uncertainty that ultimately results in human resources becoming depressed, losing self-confidence and have a low organizational commitment (Elias, 2009).

The attitude of human resources that serve in a school organization is very important in catalyzing the organization to deal with the process of change and transformation that is complex in the educational landscape (Susanty et al., 2013). The school organization is certainly able to achieve all the desired aspirations and vision if all human resources serving in it have a positive attitude, open, and always ready for the challenges of change (Eby et al., 2000). When all human resources serving in the organization have a positive attitude and are ready to face the changes that occur, then these human resources will be a very valuable asset to the school organization (Thi and Hai, 2019).

Human resources serving in a school organization need to look at the challenges of change that occur from a positive angle and not just maintain old practices that are being practiced. Instead human resources should strive to find new knowledge and skills relevant to the task being performed. This relevant new knowledge and skills can only be acquired when human resources implement the learning process continuously. The dissemination and sharing of new knowledge and skills acquired to all human resources serving in the school organization will add value to the organization and enable the school organization to be a superior competitor.

More emphasis should be given to the need to change the quality of thinking and behavior in the process of managing change that can be achieved through the implementation of learning organization practices. This is because the practice of learning organization supports the learning process among human resources at every level and in turn produces more positive change consciously (Pedler \& Burgoyne, 2017). Support and affirmation is very necessary to be given to human resources who try to carry out the learning process to strengthen their knowledge and skills. This support and affirmation will be a driving factor that will enable human resources to increase efforts to acquire useful knowledge and replace knowledge that is no longer relevant to be applied in day-to-day work processes. The failure of organizational leaders to appreciate the efforts made by human resources will lead to a decrease in the extrinsic and intrinsic motivation possessed by human resources to carry out the learning process continuously. In fact, school organizational leaders need to be aware and sensitive to the interests of human resources in giving birth to brilliant school achievements and always provide intellectual encouragement and positive reinforcement to human resources who are committed to carrying out the learning process.

\subsection{Learning Organization}

The concept of the learning organization is not new and has long been discussed in the field of management over the past three decades. Initially, this concept gained more ground in the management of profit-based organizations but in line with current changes, researchers see the need for this concept to be implemented in non-profit organizations such as school organizations (Fullan 2011). The need for school organizations to transform into learning organizations is driven by the benefits that will be received by school organizations through the implementation of learning organization practices as a core in service. Most scholars in this field believe that when a school organization 
successfully implements the practice of learning organization, the school organization will be able to produce encouraging performance and be a superior competitor in the field.

Most scholars in this field agree that to empower school organizations to meet the challenges of change and transformation, learning is the only effective solution. This is since school organizations that can learn further and eventually improve the knowledge and skills possessed by human resources have a higher competitive advantage (Voolaid \& Ehrlich, 2017). Therefore, school organizations are now not only required to become a teaching organization but must immediately transform into a genuine learning organization. This is in line with the opinion of scholars who state that to enable school organization to be more adaptive and flexible to the challenges of dramatic change and transformation, school organization now not only needs to play a role as a teaching organization but also needs to be an effective learning organization (Fedai et al., 2016).

A learning organization is an organization that constantly changes itself through the learning process. A learning organization also refers to an organization that has an effort to acquire relevant knowledge and skills and then disseminates the knowledge and skills possessed to all human resources to achieve the mission and vision efficiently and impressively. (Al-dhuwaihi et al., 2020). The learning organization will take advantage of the learning process implemented in the organization to change itself at the right time. The learning process that takes place in a learning organization is not only limited to the individual level but also occurs at the team level which ultimately contributes to the improvement of organizational knowledge. this is because the learning process implemented in the organization is defined as a complex process of finding a path that emerges from training in overcoming the challenges that occur daily and driving change (Chia, 2017). Therefore, transformation and transition for school organization into a learning organization is an imperative action that is much needed in the 21 st century.

\subsection{METHODOLOGY}

\subsection{Research Design}

This study is a quantitative study that uses a survey approach and uses descriptive design. The survey research method was chosen because according to Marican (2006) survey research is suitable to be used to obtain information from many respondents that involves hundreds of respondents. Descriptive design is a study that uses statistics to describe the characteristics of a group of samples involved in the study (Boon \& Hasan, 2011). Quantitative data obtained through this study was used to measure the level of implementation of learning organizations in fifteen school organizations located in the district of Central Melaka, Melaka.

\subsection{Population and Sample Study}

According to Creswell (2002), population refers to the entire group of individuals involved to obtain information regarding a study. The study population should contain all the information needed in the study. The study sample refers to some individuals from the same population who are involved and selected in the study. Researcher uses the cluster random sampling method as this study involves a large population size. The study involved 500 respondents selected by cluster random sampling and simple random sampling consisting of secondary school teachers serving in the district of Melaka Tengah, Melaka.

\subsection{Research Instrument}

Questionnaire forms were used in this study to obtain the required data. The questionnaire instrument is the researcher's choice as the use of questionnaires is very suitable for the survey method because the use of questionnaires can measure the attitude, opinion, or achievement of a large number of variables involved in the study.

The questionnaire instrument used was modified from the Learning Organization Practices Profile (LOPP) instrument developed by O'Brien (1994). This instrument is the researcher's choice because this instrument is more pragmatic and holistic and suitable to be used to measure the level of implementation of school organization practices. Previously, this instrument was more used in studies involving private organizations, factories, and corporate organizations than educational-based organizations such as school organizations.

Based on the LOPP instrument developed by O'Brien (1994), the implementation of learning organization practices involves three main aspects namely leadership, system and work structure, and staff development and performance. Twelve components need to be taken into account by the school organization to successfully implement the learning organization practices.

In this study, the researcher has divided the mean score for each item obtained into three parts as formulated by Marquadt (1999) (Kudus et al., 2011). These three levels consist of low levels that range from a mean value of 1 to 2.33 , a moderate level that is from a mean value of 2.34 to 3.67, and a high level that is from a mean value of 3.68 to 5.00. The interpretations for each level are shown in Table 1 .

Table 1 - Interpretation of Mean Value.

\begin{tabular}{lcl}
\hline \multicolumn{1}{c}{ Mean Value } & Level & \multicolumn{1}{c}{ Learning Organization Indicator } \\
\hline 1 until 2.33 & Low & Organizations need to redesign and develop specific Action Plans and Strategies. \\
2.34 until 3.67 & Moderate & Need to focus more on continuous improvement efforts \\
3.68 until 5.00 & High & The learning organization environment is evolving and achievable \\
& & \\
\hline
\end{tabular}




\subsection{Pilot Study}

A pilot study was conducted to enable reliability testing to be carried out. In this study, the value of Cronbach's Alpha for the LOPP questionnaire item was 0.78 and indicates that this item is at a moderate level and can be used in this study. The issue of the validity of the content of this instrument does not exist because this questionnaire has been used by Iskandar (2000) n his study conducted at Universiti Utara Malaysia and Shahrin (2000) in his study conducted at Universiti Teknologi Malaysia. Several improvements and modifications have been implemented in this questionnaire to suit the context of the school organization studied.

\subsection{Data Analysis}

Data obtained through this study were analyzed using Statistical Package For Social Science (SPSS) software 25. Descriptive analysis methods were used such as frequency percentage calculation, mean and data are arranged in Table 2.

Table 2 - Research Objective and Data Analysis

\begin{tabular}{ll}
\hline Research Objective & Data Analysis \\
\hline $\begin{array}{l}\text { To measure the level of Learning Organization practices in } \\
\text { thirteen secondary schools in the central Melaka district, }\end{array}$ & $\begin{array}{l}\text { Descriptive statistical analysis to describe the percentage frequency } \\
\text { and the mean value of the mean }\end{array}$ \\
Melaka.
\end{tabular}

\subsection{RESULTS}

4.1 Descriptive Analysis of the Level of Learning Organization Practices in Two Primary Schools in the Central Melaka District, Melaka

This study was conducted to identify the perception of human resources, namely teachers on the level of implementation of learning organizations in the school organization studied. Questionnaires were distributed to 500 respondents selected by cluster random sampling and simple random sampling. All respondents serve in secondary schools in the district of Melaka Tengah, Melaka. Quantitative data obtained through this study were analyzed using SPSS 25.0 software which involves descriptive statistics that is the calculation of mean values.

Table 3 below shows the position of the twelve components contained in the practice of learning organization according to the LOPP Model developed by O'Brien (1994) which includes three main aspects namely leadership, system and work structure, and staff development and performance. Based on the table above, the following is a description related to three (3) aspects namely leadership, systems and work structure and development, and staff performance as well as based on twelve (12) components of learning organization practice.

On average, the mean value to determine the position of learning organization practice based on the three main aspects is in the range of 4.00 to 4.09 . High mean readings for all three aspects indicate that human resources serving in the school organizations studied tend to agree that the practice of learning organizations has been practiced and is evolving in their schools. A comparison between the three aspects of learning organization shows that the leadership aspect recorded the highest mean value of 4.09 and followed by the system and structure aspects of work with a mean value of 4.08. The aspect of a learning organization that recorded the lowest mean value is the aspect of staff development and performance that recorded a mean value of 4.00. This shows that the school organizations studied need to strengthen the development and performance aspects of staff in realizing the school as a superior learning organization.

Table 3 - Level of Learning Organization Practices

\begin{tabular}{|c|c|c|c|c|}
\hline No & Learning Organization Practices & Min & $\begin{array}{l}\text { Standard } \\
\text { deviation }\end{array}$ & Level of Practice \\
\hline \multicolumn{5}{|c|}{ Aspects: Leadership } \\
\hline 1 & Vision and strategy & 4.07 & 0.56 & High \\
\hline 2 & Executive practices & 4.15 & 0.56 & High \\
\hline 3 & Management Practices & 3.96 & 0.62 & High \\
\hline \multirow[t]{2}{*}{4} & Organizational Climate & 4.18 & 0.58 & High \\
\hline & Mean & 4.09 & 0.58 & High \\
\hline \multicolumn{5}{|c|}{ Aspects: System and Work Structure } \\
\hline 5 & Work Systems and Organizations & 4.01 & 0.58 & High \\
\hline 6 & Information Flow & 4.16 & 0.52 & High \\
\hline 7 & Individual and Group Practices & 4.08 & 0.53 & High \\
\hline \multirow[t]{2}{*}{8} & Work Processes & 4.06 & 0.48 & High \\
\hline & Mean & 4.08 & 0.53 & High \\
\hline \multicolumn{5}{|c|}{ Aspects: Staff Development and Performance } \\
\hline 9 & Performance Goals and Feedback & 3.98 & 0.52 & High \\
\hline 10 & Training and Education & 4.02 & 0.54 & High \\
\hline 11 & Rewards and Recognition & 3.94 & 0.61 & High \\
\hline \multirow[t]{3}{*}{12} & Individual and Group Development & 4.05 & 0.53 & High \\
\hline & Mean & 4.00 & 0.55 & High \\
\hline & Average & 4.06 & 0.55 & High \\
\hline
\end{tabular}


Based on the table above, all twelve (12) components of the practice of learning organization are at a high level and have a mean value exceeding 3.68. The three components of learning organization practice recorded a mean reading below 4.00 namely performance and feedback goals, management practices, and rewards and services. Therefore, the school organizations studied need to emphasize these four components to ensure that the school organization successfully transforms into a learning organization. Overall, it can be concluded that all three aspects of learning organization in the school organizations studied are evolving.

\subsection{DISCUSSION AND RECOMMENDATION}

The changes that have taken place in the landscape of the educational environment have provided a very clear indicator for school organizations to change existing practices towards a more excellent practice. These efforts are important to enable school organizations to remain sustainable and relevant despite the challenges of dynamic change. To enable school organizations to achieve compatibility with the stimuli of change in the environment, it is very necessary for school organizations to make the learning process as the core of services in enabling school organizations to find the best solutions to be able to survive and overcome the forces of change.

The implementation of learning organization practices in the school organizations studied is guided and based on the Malaysian Education Blueprint (MEB) 2013-2025. This plan is a shift of change that has been introduced by the Ministry of Education Malaysia which aims to strengthen the education system in Malaysia to be on par with the education system of developed countries (Malaysia Education Blueprint Malaysia 2013). This plan is a paradigm shift that enables school organizations to cope with the internal and external changes taking place in the national education landscape.

The transformations and changes taking place in the national education landscape triggered by the process of globalization and the industrial revolution 4.0 demand school organizations to immediately change existing practices that are practiced. Changes in existing practices are very important to enable school organizations to be able to meet the needs of stakeholders and then realize the goals of the national education system in producing and preparing human capital that can drive national progress and face a rapidly changing, more complex, and the interdependent world (Williams et al., 2012). However, the question that remains hovering among researchers is what are the best practices that can prepare school organizations to face this challenge as well as ensure that school organizations can maintain sustainability and remain relevant. Therefore, school organizations throughout the country need to immediately implement a practice that can be applied in the organization and become an important foundation in the day-to-day work of the school organization.

The findings of this study further strengthen the findings of the study obtained by Chin (2014) and Boon and Hassan (2011) who confirmed that school organizations in Malaysia are committed to implementing learning organization practices to produce encouraging school organizational performance. Aspects of staff development and performance that recorded low mean readings compared to aspects of leadership and systems and work structure in this study are in line with the findings of Chin (2014) and provide a clear indication to organizational leaders to emphasize this aspect for successful implementation of learning organization practices. in the school organization.

This study sees schools as an open system that faces additional complex effects than closed systems (Wahidin, 2013). Through this theory, school organizations are seen not to operate statically but instead are influenced by changes that occur in the landscape of the national educational environment. The school organizations studied are also facing various changes in line with the current changes driven by the process of globalization and the industrial revolution 4.0.

Most scholars in this field agree that to empower school organizations to meet the challenges of change and transformation, learning is the only vehicle and the most effective solution. This is because school organizations that can learn further improve the knowledge and skills possessed by human resources have a higher competitive advantage (Voolaid \& Ehrlich, 2017). Therefore, school organizations are now not only required to become a teaching organization but must immediately transform into a genuine learning organization. This is in line with the opinion of scholars who state that to enable school organization to be more adaptive and flexible to the challenges of dramatic change and transformation, school organization now not only needs to play a role as a teaching organization but also needs to be an effective learning organization (Fedai et al., 2016).

Although the findings of this study are meaningful and able to be an important indicator to all stakeholders but this study still has limitations of the study. This study is limited to represent the district of Central Melaka, Melaka. For future studies, it is proposed that a study be implemented to measure the level of learning organization practice in school organizations throughout Malaysia to obtain a more accurate and comprehensive result using LOPP instruments. A comparative study should also be conducted to compare the level of learning organization practices in schools that have high, medium and weak performance to study the relationship between the implementation of learning organization practices with school performance.

\subsection{CONCLUSION}

This study describes the application of cultural practices of learning organization in 15 secondary schools located in the district of Melaka Tengah, Melaka based on the perception of the main human resource serving in the school, namely teachers. This study uses a modified questionnaire instrument from LOPP that was developed by O'Brien (1994). The most practiced components in the school organization studied are organizational climate, information flow and executive practices while the least practiced and need to be given more emphasis are the reward and recognition component, management practices and performance goals and feedback.

The findings of this study provide an overview of the cultural manifestations of LO in the school organizations studied. In addition, the findings of this study can also be an indicator and guide for policy makers and implementers to plan and formulate strategies towards the successful implementation of learning organization practices in school organizations. 


\section{References}

Abenga, E. S. B. (2018). Applicability of the learning organisation idea to universities in Kenya. Educational Research and Reviews, 13(23), 745-753. https://doi.org/10.5897/err2018.3607

Al-dhuwaihi, A., Alzahrani, Y., Abdulrahman, I., Faisal, B., \& Arabia, S. (2020). The Degree of Achievement of Learning Organisation Dimensions in the Schools of the Royal Commission in Jubail by Using Senge 's Model. International Journal of Innovation, Creativity and Change, 14(12), 181-202.

Alzahrani, S. M. H., Hammersley-Fletcher, L., \& Bright, G. (2016). Identifying Characteristics of a "Good School" in the British and Saudi Arabian Education Systems. Journal of Education 136-148. http://ezproxy.lib.ucalgary.ca/login?url=http://search.ebscohost.com/login.aspx?direct=true\&db=eric\&AN=EJ1115939\&site=ehost-live

Boon, Y., \& Hasan, F. (2011). Tahap Amalan Organisasi Pembelajaran Di Sebuah Sekolah Menengah Daerah Kulaijaya, Johor. Journal of Educational Management, $4,18-33$.

Chia, R. (2017). The Learning Organization Article information : The Learning Organization, 22(1), 40-57.

Chin, K. L. (2014). Ciri-ciri Organisasi Pembelajaran Mengikut Persepsi Guru Di Sekolah-Sekolah Menengah Di Malaysia. Universiti Malaya.

Dahl, K. K. B. (2019). Professional development lost in translation? 'Organising themes' in Danish teacher education and how it influences student-teachers' stories in professional learning communities. Research in Comparative and International Education, 14(3), 357-375. https://doi.org/10.1177/1745499919865141

Donehower Paul, C., Bukaty, C. A., \& Dieker, L. (2020). Teacher professional learning using simulation: a Delphi study. Teacher Development, 24(1), 21-32. https://doi.org/10.1080/13664530.2019.1694574

Elias, S. M. (2009). Employee commitment in times of change: Assessing the importance of attitudes toward organizational change. Journal of Management, 35(1), 37-55. https://doi.org/10.1177/0149206307308910

Fedai, L., Gazi, Z. A., \& Aksal, F. A. (2016). Developing a Scale for Schools as Learning Organizations towards Quality Culture. International Journal of Educational Sciences, 15(1-2), 96-102. https://doi.org/10.1080/09751122.2016.11890517

Firdaus, A. M. N., Shukor, K. A., \& Jasmi, K. A. (2016). Pembinaan Hubungan Di Antara Guru Dengan Pelajar. Jurnal Teknilkal \& Sains Sosial, 14(4), 4-6.

Firdaus, R. (2016). Analisis Penerapan Learning Organization di Badan Kepegawaian Pendidikan dan Pelatihan Daerah Kabupaten Luwu Timur. Ibnu Khaldum, 11(3), 698-708.

Garvin, D. A., Edmondson, A. C., \& Gino, F. (2008). Is yours a learning organization? In Harvard Business Review (pp. 1-10). Harvard Business School Press.

Ghadermarzi, H., Ataei, P., Karimi, H., \& Norouzi, A. (2020). The learning organisation approaches in the Jihad-e Agriculture Organisation, Iran. Knowledge Management Research and Practice, OO(00), 1-11. https://doi.org/10.1080/14778238.2020.1767520

Harris, A., \& Jones, M. (2018). Leading schools as learning organizations. School Leadership and Management, 38(4), 351-354. https://doi.org/10.1080/13632434.2018.1483553

Hashim, S. (2000). UTM Kearah Sebuah Organisasi Pembelajaran. Satu Tinjauan. Universiti Teknologi Malaysia

Jassa, I. (2000). Amalan Organisasi Pembelajaran Di Universiti Utara Malaysia : Dari Perspektif Kakitangan. Universiti Utara Malaysia

Malaysian Ministry of Education (2013). Malaysia Education Blueprint 2013-2025. Putrajaya: MOE.. https://doi.org/10.1016/j.tate.2010.08.007

Kudus, N., Sidek, S., Hussin, S., \& Hassan, M. A. (2011). Learning Organization Practices as Human Resource Development for Transformational Change at UTeM. Journal of Human Capital Development, 4(2), 117-128.

Marquardt, M. J. (2002). Building the Learning Organization: Mastering the 5 Elements for Corporate Learning. Nicholas Brealey International.Marican, S. (2006). Penyelidikan Sains Sosial : Pendekatan Pragmatik. Edusystem Publisher.

Mei, T. S., Teong, L. K., Shaari, A. S., \& Yusof, A. A. (2017). Hubungan Keadilan Penilaian Prestasi Dengankomitmen Organisasi Guru. Proceedings of the ICECRS, 1(1), 139-146. https://doi.org/10.21070/picecrs.v1i1.590

Mohd-zainal, A., Yusof, S. M., \& Goodyer, J. (2017). Validity, Reliability and Variations of Perception of Dimensions of Learning Organisation At Different Organisational Levels in Malaysian Manufacturing. Jurnal Mekanikal, 40(June), 37-52.

Odor, H. O. (2018). A Literature Review on Organizational Learning and Learning Organizations. International Journal of Economics \& Management Sciences, 07(01), 1-6. https://doi.org/10.4172/2162-6359.1000494

Pedler, M., \& Burgoyne, J. G. (2017). Is the learning organisation still alive? Learning Organization, 24(2), 119-126. https://doi.org/10.1108/TLO-12-2016-0087

Prenger, R., Poortman, C. L., \& Handelzalts, A. (2019). The Effects of Networked Professional Learning Communities. Journal of Teacher Education, 70(5), 441452. https://doi.org/10.1177/0022487117753574

Retna, K. S., \& Tee, N. P. (2006). The challenges of adopting the learning organisation philosophy in a Singapore school. International Journal of Educational Management, 20(2), 140-152. https://doi.org/10.1108/09513540610646127

Sabariah Sharif, Aishah Tamby Omar, \& Suhaiman Mondus. (2013). Organisasi Pembelajaran dan Hubungannya dengan Kepuasan Kerja. MANU Jurnal Pusat Penataran Ilmu \& Bahasa, 19, 183-212.

Santa, M. (2015). Learning organisation review - a "good" theory perspective. The Learning Organization, $22(1), 40-57$.

Savas, A. C., Dos, I., Dos, B., \& Demir, H. (2013). Experiencing a learning organization: School administrators identify causes of teacher ineffectiveness. Anthropologist, 16(1-2), 417-425. https://doi.org/10.1080/09720073.2013.11891367

Schleicher, A. (2012). Preparing Teachers and Developing School Leaders for the 21st Century. https://doi.org/10.1787/9789264174559-en

Stoll, L., \& Kools, M. (2017). The school as a learning organisation: a review revisiting and extending a timely concept. Journal of Professional Capital and Community, 2(1), 2-17. https://doi.org/10.1108/jpcc-09-2016-0022

Susanty, A., Miradipta, R., \& Jie, F. (2013). Analysis of the Effect of Attitude Toward Works , Organizational Commitment , and Job Satisfaction ,. European Journal of Business and Social Sciences, 1(10), 15-24.

Thi, K., \& Hai, T. (2019). Influenced Factors on Employees' Attitudes toward Organizational Change at Vietnam-Hungary Industrial University. International Journal of Managerial Studies and Research, 7(5), 7-15. https://doi.org/10.20431/2349-0349.0705002

Van Wart, M., Roman, A., Wang, X. H., \& Liu, C. (2017). Integrating ICT adoption issues into (e-)leadership theory. Telematics and Informatics, 34(5), 527-537. https://doi.org/10.1016/j.tele.2016.11.003

Vijayabanu, C., Renganathan, R., \& Govindarajan, K. (2015). The upshot of the learning organisation: Case study of an indian private-sector bank using the PLS-SEM model. Journal of Organisational Transformation and Social Change, 12(2), 178-192. https://doi.org/10.1179/1477963315Z.00000000041

Voolaid, K., \& Ehrlich, Ü. (2017). Organizational learning of higher education institutions: the case of Estonia. The Learning Organization, 24(5), 340-354.

Wahidin, U. (2013). Peran Budaya Organisasi Pendidikan Islam dalam Menghadapi Tantangan Pembangunan Masyarakat, Negara dan Bangsa. Edukasi Islami Jurnal Pendidikan Islam, 02, 397-407.

Williams, R., Brien, K., \& LeBlanc, J. (2012). Transforming Schools into learning organizations: Supports and Barriers to Educational Reform. Canadian Journal of Educational Administration Policy, and July(134), http://www.umanitoba.ca/publications/cjeap/pdf_files/williams_brien_leblanc.pdf\%5Cnhttp://www.umanitoba.ca/publications/cjeap/archives.html 